講座

\author{
新しい栄養学 (I) \\ リポタンパク質 \\ 大 野 佳 美* 原 一 郎** \\ $*$ 山陽学園短期大学 (岡山市平井 1-14-1) \\ ** 東京医科歯科大学教養部 (市川市国府台 2-8-30)
}

\title{
New Aspects on Nutrition
}

\section{(1) Lipoprotein}

\author{
Yoshimi OHNo* and Ichiro HaRA**
}

* Sanyō Gakuen Junior College (1-14-1, Hirai. Okayama)

** Tokyo Medical and Dental University (2-8-30, Kōnodai, Ichikawa, Chiba)

\section{はじめに}

昭和 54 年に改正された日本人の栄養所要量は今後昭 和 60 年までを目標としており, 日本人として健康の維 持, 増進のために望ましいとされる各栄養素一タンパク 質, 炭水化物 (糖質), 脂質, ビタミン, 及びミネラルー の摂取基準を示したものである。一方，国民の栄養状態 及び栄養摂取の実態などをはあくするために毎年行われ ている国民栄養調查の結果をみると，ここ数年間は全国 平均では, カルシウム, ビタミン $\mathrm{A}$, ビタミン $\mathrm{B}_{2}$ が若 干下まわっているものの, タンパク質, 鉄, ビタミン $\mathrm{C}$, ビタミン $\mathrm{B}_{1}$ は所要量に達しておうり, 一昔前の高炭 水化物低タンパク質捸取の傾向がみられなくなった。し かし，個別的にみると，例えば，タンパク質の摂取量が $60 \mathrm{~g}$ 未満の世帯ではエネルギー, タンパク質, カルシ ウム, 鉄, ビタミン $\mathrm{A}$, ビタミン $\mathrm{B}_{2}$, ビタミン $\mathrm{C}$ な どの摂取量が栄養所要量に達していない反面, タンパク 質摂取量が $90 \mathrm{~g}$ 以上の世帯ではエネルギー, タンパク 質, 及び動物性脂質の過剩攝取の傾向があり, 各個人間 あるいは世帯間ではまだまだ栄養摂取状況にかなりの格 差がみられるのが事実である。また, 朝食を食べなかっ たり，食べてもパンとコーヒーだけですますという人も 少なくない。てばやく空腹を満たすためのインスタント 食品やスナック菓子類なども豊富に存在する。このよう にタンパク質や鉄不足など低栄養に起因する貧血の発現 率が高、現象がみられる反面, 近年の魚, 野菜類や米離 れと動物性食品の摂取率の増加や脂肪摂取増に伴い高血
圧, 高脂血症, 及び動脈硬化などいわゆる成人病の発生 率のパターンが欧米のそれに似てきたともいわれてい る。また, 欧米では日本の在来の食生活が見なおされて きているといわれる。

これらの成人病予防のために日常の食生活が重要視さ れており, 成人病の発生と関連して食べ物や栄養に関心 がもたれてきている。では, 今日, 常に “栄養”を念頭 におき，各栄養素のバランスを考慮した食生活を心がけ ている人々は何人くらいいるだろうか?

このシリーズでは, 食べ物に含まれている各栄養素や 今日の食生活に関連して最近注目されてきている事など を中心として述べることによって話題を提供できれば幸 いである。

\section{1 リポタンパク質}

近年, 日本人の食生活の欧米化に伴い, 成人病特にア テローム性動脈硬化症と関連して血液中のリポタンパク 質やコレステロールの含量及びその組成の変動が注目さ れてきている。

リポタンパク質はタンパク質, リン脂質, コレステロ ール及びトリグリセリドから構成されており，肝臟や小 腸粘膜で生成されることが明らかにされている。血液中 では, 生体内で生成された水に不溶の脂質を他の組織や 器管に運搬する作用を行っており，これらリポタンパク 質の異化については, リポタンパク質の種類により異な ると考えられているが肝臓及び肝臟以外の組織としてじ ん藏が異化の場所として明らかにされている11。また， 
これらリポタンパク質の代謝過程においては, リポプロ テインリパーゼ (lipoprotein lipase, LPL) とレシチン ・コレステロールアシルトランスフェラーゼ (lecithincholesterol acyltransferase, LAAT) の 2 つの酵素が重 要な役割を行っている。LCAT は血しょう中に存在し， レシチンの 2 位の脂肪酸アシル基をコレステロールのヒ ドロキシル基に転移させる反応を触媒する酵素であり， 血液中のコレステロールエステルのほとんどがこの反応 でつくられる。LPL は脂肪組織, 筋肉, 心筋中に存在 し，これらの組織の毛細血管内皮細胞の表面でカイロミ クロンや超低密度リポタンパク質に存在するトリグリセ リドの $\alpha$ 位に作用してこれを水解する酵素である。ま た，LPL は通常血中には存在せずヘパリン静注後数分 以内に血しょう中に放出されることが認められている。

ここ 10 数年間にリポタンパク質の研究が急速にす寸 み，リポタンパク質の構造，機能及び代謝などに関する 報文や総説が数多〈出ている(1) 5)ので詳しくはそれらを 参照されたい。ここでは主としてリポタンパク質の構 造, 組成を簡単に延べ, これらと成人病とに関連した事 柄についていくつかの論文を紹介したい。

\section{2 リポタンパク質の構造と組成}

リポタンパク質はその比重によって軽いものからカイ ロミクロン[chylomicrons $(d \leqq 1.006)]$, 超低密度リポタ ンパク質 [very low-density lipoproteins (VLDL, $d \leqq$ 1,006)], 低密度リポタンパク質[low-density lipoproteins (LDL, $1.006 \leqq d \leqq 1.063)]$, 高密度リポタンパク質 [highdensity lipoproteins (HDL, $1.063 \leqq d \leqq 1.210$ )] 及び超 高密度リポタンパク質 [very high-density lipoproteins
(VHDL， $d>1.210$ )]に分類され，これはまた粒子の大 きさに逆比例している。このうち, HDL はさらに $\mathrm{H}=$ $\mathrm{DL}_{2}(1.063 \leqq d \leqq 1.125)$ と $\mathrm{HDL}_{3} \quad(1.125 \leqq d \leqq 1.210)$ に分かれ，これらのほかにも VLDL と LDL の中間体 としてのリポタンパク質 [intermediate low-density lipoproteins (ILDL または IDL $1.006 \leqq d \leqq 1.019$ )] の存在も認められている。

粒子が小さくなり密度が増すに従って，トリグリセリ ド (TG) 含量が減少し，コレステロール，リン脂質及 びタンパク質含量が増加する。すなわち, カイロミクロ ンや VLDL ではトリグリセリド含量が 90〜 50\% も含 まれ，タンパク質含量が極めて少ないが，LDLや HDL の主成分はコレステロール，リン脂質及びタンパク質で ある $(\text { 表-1 })^{6)}$ 。リン脂質の主要なものはホスファチジル コリン $(\mathrm{PC})$ とスフィンゴミエリン (SM) である。コ レステロールに対する総リン脂質の割合，SM に対する PC 量の比は VLDL の方が LDL よりも高い。また, 遊離コレステロールに対するコレステロールエステルの 比は HDL に扔ける方が VLDL よりも高い。

これらリポタンパク質の各含量は動物によっても異な り，犬，ラットでは VLDL，LDL が少なく HDL が高 いが，人では，LDL が主要リポタンパク質であり，総 リポタンパク質の約 $50 \%$ を占め，血しょうコレステロ ールの約 70\% が LDL に存在する。また，年令ととも に VLDL，LDL 量が増加し，男性よりも女性の方が HDL 量が 30〜60\% 高い。

リポタンパク質の主要成分の一つであるタンパク質部 分 (アポタンパク質)の主なものを表-2'依した。これ らおのおののアポタンパク質の性質についてもかなり調

表-1 リポタンパク質の組成 ${ }^{6)}$

\begin{tabular}{|c|c|c|c|c|c|c|c|c|}
\hline & $\left(\times 10^{-6}\right)$ & $\begin{array}{c}\text { 分子の大きさ } \\
\left(\mathrm{A}^{\circ}\right)\end{array}$ & 密 度 & $\begin{array}{c}\text { トリグリセリ } \\
(\%)\end{array}$ & ド遊離コレステ & 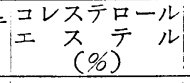 & $\begin{array}{c}\text { リソ脂質 } \\
(\%)^{-1}\end{array}$ & $\begin{array}{c}\text { タンパク質 } \\
(\%)\end{array}$ \\
\hline Chylomicrons & 504 & $>750$ & 0.93 & 84 & 2 & 5 & 7 & 2 \\
\hline VLDL & 19.6 & $280 \sim 750$ & 0.97 & 50 & 7 & 12 & 18 & 8 \\
\hline LDL & 2.3 & $210 \sim 250$ & 1.035 & 11 & 8 & 37 & 22 & 21 \\
\hline $\mathrm{HDL}_{2}$ & 0.36 & $200 \sim 225$ & 1.09 & 4.5 & 5.4 & 16 & 30 & 41 \\
\hline $\mathrm{HDL}_{3}$ & 0.18 & $60 \sim 140$ & 1.15 & 4.1 & 2.9 & 12 & 23 & 55 \\
\hline VHDL & 0.15 & $40 \sim 100$ & 1.155 & 4.6 & 0.3 & 3 & 28 & 62 \\
\hline
\end{tabular}

表-2 ホポタンパク質の組成1)

\begin{tabular}{|c|c|c|c|c|c|c|c|c|}
\hline & $\begin{array}{l}\text { Apo A-I } \\
\phi_{6}^{*}(\mathrm{mg} / \mathrm{dl})\end{array}$ & $\begin{array}{r}\text { Apo A-II } \\
\%(\mathrm{mg} / \mathrm{dl})\end{array}$ & $\underset{\%(\mathrm{mg} / \mathrm{dl})}{\mathrm{Apo} \mathrm{B}}$ & $\begin{array}{l}\text { Apop C-I } \\
\%(\mathrm{mg} / \mathrm{dl})\end{array}$ & $\underset{\%(\mathrm{mg} / \mathrm{dl})}{\text { Apo C-II }}$ & $\begin{array}{l}\text { Apo C-III } \\
\%(\mathrm{mg} / \mathrm{dl})\end{array}$ & $\underset{\%(\mathrm{mg} / \mathrm{dl})}{\text { Apo D }}$ & $\begin{array}{c}\text { Apo E } \\
\%(\mathrm{mg} / \mathrm{dl})\end{array}$ \\
\hline Chylomicrons ${ }^{a)}$ & 7.4 & 4.2 & 22.5 & 15 & 15 & 36 & & \\
\hline$\left.V_{L D L}{ }^{b}\right)$ & Tr. & Tr. & 36.9 & 3.3 & 6.7 & 39.9 & & 13.0 \\
\hline $\mathrm{LDL}^{\mathrm{b})}$ & & & 98 & Tr. & Tr. & $\operatorname{Tr}$ & & $\operatorname{Tr}$. \\
\hline $\mathrm{HDL}$ & 6.7 & 22 & $\operatorname{Tr}$. & $1 \sim 3$ & $1 \sim 3$ & $3 \sim 5$ & + & + \\
\hline
\end{tabular}

* Apo A-I は Apoprotein A の略で通常はこれを用いる。以下同様である。

a) リンパ液, b) 血しょう

（注） apoprotein C-I，C-II，C-III については $\mathrm{HDL}_{2}$ の方が $\mathrm{HDL}_{3}$ よりも多いという報告がある。 $3 \sim 5 \% \mathrm{HDL}_{2}, 1 \sim 2 \% \mathrm{HDL}_{3}$ 
べられており，その一次構造も明らかにされている77.8)。 カイロミクロンにはアポタンパク質は 1\%以下しか存在 せず，HDL には $50 \%$ 以上存在する。また, 各リポタ ンパク質でのアポタンパク質の種類及び含量が異なり, apoprotein A-I , A-II は HDL の主要アポタンパク質 であるが，LDL においては主なものは apoprotein B で ありこのタンパク質は VLDL, ILDL にもかなり存在 する。apoprotein C-I, C-II, C-IIIは VLDL, HDL に 存在する。これらのほかに, VLDL 画分から得られた “Arginin-rich proteins”または apoprotein E と呼ばれ るものや HDL に含まれる “Thin-line protein”または apoprotein D とよばれるアポタンパク質がある。これ らの研究から生合成の過程は肝臟で VLDL が生成され 血中で既述の酵素の作用で LDL になり組織にとり込ま れる。また HDL は肝臟で別に生成する。しかし, IDL 中に apoprotein B が存在することから，VLDL からトリグリセリドや apoprotein C が除かれて IDL になったものと考えられる。

これらリポタンパク質の主要な各成分がどのように組 みあって立体構造をとっているのか？ 図-1 に $\mathrm{HDL}_{3}$ についての Edelstein らのモデルを示した9”。

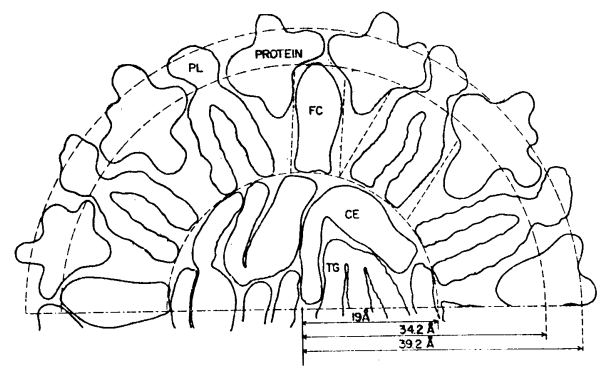

$\mathrm{PL}$ リン脂質 $\mathrm{FC}$ 遊離コレステロール $\mathrm{CE}$ エステルコレステロール TG トリグリセリド 図-1 人 $\mathrm{HDL}_{3}$ の構造モデル

\section{3 リポタンパク質と疾病}

我が国では脳卒中や胃がんが減少し, 動脈硬化性心疾 患や乳がん, 腸がんが増加する傾向にある。最近，この
動脈硬化症特にアテローム性動脈硬化(かゆ状硬化) と関 連して血液中のコレステロール含量やリポタンパク質の 量及び組成の変動が注目されてきている。アテローム性 動脈硬化では動脈壁の病変部にたくさんのコレステロー ルや脂肪の蓄積がみられ，また多くの心筋こうそくや狭 心症などの心臓病をはじめとして脳こうそくといわれる 脳卒中の大部分もこのアテローム性硬化によっておこ る。アテローム性硬化をおこしている血管壁を調べてみ ると，その脂肪の大部分はコレステロールとリン脂質で あり，少量のトリグリセリドもみられる。若いころの血 管にはリン脂質が多いことからこの疾病の進行にはコレ ステロールが大きく影響していると考えられ，従ってこ の動脈硬化をおこすのは血液中のコレステロールである ことが示唆される。血液中のコレステロールのほとんど は LDLによって体の他の組織に運ばれ，一方，血管壁 やその他の組織に蓄積したコレステロールは HDL によ って再び肝㵴にもどされて，そこで処理され，コレステ ロールは胆じゅう酸となり胆じゅう中に流されていく。 すなわち，VLDL，LDL は動脈硬化に促進的に，HDL は動脈硬化を抑制するように衝くと考えられている。一 連の疫学的な研究に㧍いて, HDL-コレステロール（要 するに HDL の量) が多い者には冠状動脈硬化性心疾 患患者が少ないということがわかって以来, 特に HDLコレステロールの研究が盛んとなりまた発展してきた 10) 12)。表-3 に Gordon らの HDL-コレステロールと 冠心疾患の発生率についての報告を示したが非常によく 逆の相関がみられる。

肥満者では，このコレステロールが HDL 中で低く， VLDL，LDL で高い。この傾向は肥満の程度が強いほ ど大きく，また中性脂質の高い者ほど HDL 中のコレ ステロールが低い值を示す。一般に女性肥満者は男性肥 満者に比べて HDL 中のコレステロール量が高く, 従 ってこのことが動脈硬化が少ない原因の一つであると考 えられているが女性ホルモンの関与も推定されている。 閉経期のエストロゲン使用者では有意に HDL 特に H= $\mathrm{DL}_{2}$ のレベルが高い(13)。しかし，プロゲストロンを添 加すると $\mathrm{HDL}_{3}$ が高くなる。表-4 にホルモンについて

表-3 HDL-コレステロールと冠心疾患発生率との関係 ${ }^{10)}$

\begin{tabular}{|c|c|c|c|c|c|c|}
\hline \multirow{2}{*}{ 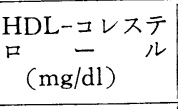 } & \multicolumn{3}{|c|}{ 男性 } & \multicolumn{3}{|c|}{ 女 性 } \\
\hline & 冠心疾患発生率 & $\begin{array}{l}\text { 危険にさらされ } \\
\text { いる人口 }\end{array}$ & $\begin{array}{l}1,000 \text { 当たり } \\
\text { の 割 }\end{array}$ & 冠心疾患発生率 & $\begin{array}{l}\text { 危険にさらされ } \\
\text { いるる }\end{array}$ & $\begin{array}{l}1,000 \text { 人当たり } \\
\text { の 割 }\end{array}$ \\
\hline 全 体 & 79 & 1025 & 77.1 & 63 & 1445 & 43.6 \\
\hline$<25$ & 3 & 17 & 176.5 & 0 & 4 & 0 \\
\hline $25 \sim 34$ & 17 & 170 & 100.0 & 11 & 67 & 164.2 \\
\hline $35 \sim 44$ & 35 & 335 & 104.5 & 12 & 220 & 54.5 \\
\hline $45 \sim 54$ & 15 & 294 & 51.0 & 19 & 386 & 49.2 \\
\hline $55 \sim 56$ & 8 & 134 & 59.7 & 14 & 353 & 39.7 \\
\hline $65 \sim 74$ & 1 & 40 & 25.0 & 3 & 216 & 13.9 \\
\hline 75 以上 & 0 & 35 & 0 & 4 & 199 & 20.1 \\
\hline
\end{tabular}


表-4 正常者における血しょう HDLーコレステロール， A-I，及び A-II レベルa),14)

\begin{tabular}{|c|c|c|c|c|c|c|c|}
\hline & 対 & 象 & 者 & $n$ & $\mathrm{HDL}-\mathrm{CH}$ & A-I & $\mathrm{A}-\mathrm{II}$ \\
\hline 全 & 男 & 性 & & 192 & 45 & 120 & 33 \\
\hline 全 & 女 & 性 & & 188 & 55 & 135 & 36 \\
\hline \multicolumn{4}{|c|}{ エストロゲン非服用者 (女性) ${ }^{\mathrm{b})}$} & 92 & 54 & 130 & 34 \\
\hline \multicolumn{4}{|c|}{ エストロゲン服用者（女性） } & 19 & 61 & 149 & 39 \\
\hline \multicolumn{4}{|c|}{$\begin{array}{l}\text { エストロゲン及びプロゲステロン } \\
\text { 服用者 (女性) }\end{array}$} & 56 & 54 & 140 & 39 \\
\hline
\end{tabular}

注 a）それぞれ脂質レベルで個々に選択された産業集団を 示す。結果は平均値 $(\mathrm{mg} / \mathrm{dl})$ で示した。

b）採血前 2 週間は薬物治療を受けていない女性集団。

の結果を示した ${ }^{14)}$ 。

運動は HDL 中のコレステロールを上昇させること が知られており，運動を続けてやっている人では対照者 に比べてHDL-コレステロールのレベルが高いことが認 められている。これはインシュリンに対する感受性がよ くなり, 脂肪組織での LPL 活性の上昇のため, HDLコレステロールが増加すると考えられる。また，60\%シ ユクロース食では VLDL 中のタンパク質の著明な増加 が観察されている。運動の程度はマラソン選手でなくジ ョギングを行っている人たちでも対照者に比べて HDLコレステロールに有意の増加がみられたという。

ねずみでは, バタ一や動物性脂肪の摂取のみでは高コ レステロール血症にはならず, コレステロールを与えて やらなければならない。また，ねずみでは，人に比べて HDL-コレステロールが 75\% と多いために動脈硬化を おこしにくいといわれている。

表-5 HDL の変動状態 ${ }^{12)}$

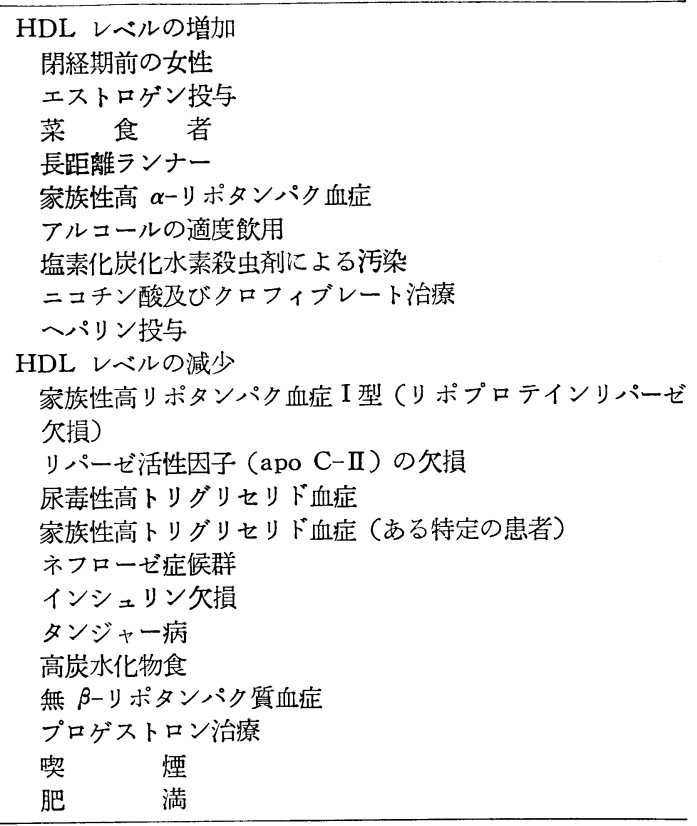

このほかにも HDL-コレステロールは糖尿病, 喫煙, ストレスなどで減少し, 逆に適度のアルコール, 多価不 飽和脂肪酸を含む食品の摂取によって上昇する。これら の結果を表-5 に示した ${ }^{12)}$ 。

このように，リポタンパク質特に HDL-及び LDLコレステロールの増減と関連してすなわち, HDL-コレ ステロールが多いと動脈硬化及びこれに起因する疾病の 䂆方に効果があるようにみられる。しかし, 血しょう中 に HDL がほとんど存在せず, 肝臓, じん臓などの組 織にコレステロールエステルが蓄積する家族性の遺伝性 疾患である Tangier 病の患者においては動脈硬化が他 の者に比べて著明にす寸んでいないこと，また HDLコレステロールが動脈硬化を防ぐという直接の証拠もみ あたらない。ラットを用いた実験では，血中コレステロ 一ル值が低くても LDL/HDL 比が高い例もあり, これ らについて単に HDL-コレステロールといらだけでな く LDL/HDL 比が重要であると考えられる。しかし, 現在では HDL-コレステロールをいかに増加させるか に関心がもたれ，これらの研究と関連して食品中の成分 が種々検討されていることは事実である。

\section{4 むすび}

個々のリポタンパク質の分画定量が可能になるにつれ てリポタンパク質特に HDL に含まれるコレステロー ル量の多い人にはアテローム性動脈硬化症が少ないとい う報告以来, リポタンパク質のこの分野での研究が急速 に進み，また，リポタンパク質の代謝や構造についての 研究も盛んに行われるようになり, 現在においても新し 、知見が次々と得られつつある。

しかし，これら疾病と食物との関連については今まで は血中総コレステロールを指標として研究されているこ とが多く, 動物性脂肪及び動物性タンパク質の過剩摂取 による肥満, 心疾患, 高脂血症及び高コレステロール血 症などの発生と同時にこれらの原因となるあるいはこれ らの因子によって誘発される動脈硬化の問題が特に関心 をもたれてきている。いうまでもなくこれらの疾病の治 療のためには医療とともに正しい食物摂取の指導が重要 となる。高コレステロール血症では, LDL-コレステロ 一ルの著明な増加がみられることから，LDL の多い人 にはコレステロールや飽和脂肪酸を多く含んでいる肉類 やその他の動物性脂肪のとりすぎに気をつけることが必 要である。一方, 多価不飽和脂肪酸特にリノール酸を多 く含む植物性油脂を豊富に含む食品の摂取がすすめられ ている。しかし，これもとりすぎると HDL の量を減 少させるといわれ, 動物性脂肪と植物性脂肪の比が 1 : 2 の割合で摂取することが望ましいとされ，また，野菜 など䋐維の多い食品にはコレステロールを下げる作用が あるといわれている。 
このように, 食品には多くの成分が共存しており, 単 にコレステロール含量が多いといら理由から摂取をさけ なければならないというのではなく, 食品成分のなかに はコレステロールまたは特定のリポタンパク質の増減に 関与しているものがあるのでいろいろな種類の食品を組 み合わせ，いわゆる栄養のかたよりをさけ，バランスの とれた食事内容を心がけることが必要である。このこと は, リポタンパク質やコレステロールにかぎったことで はなくすべてにあてはまることである。

コレステロールについては次回でもっと詳しく述べる 予定である。

(昭和 56 年 5 月 18 日受理)

\section{文献}

1) E.J., Schaefer, S. Eisenberg, R.I. Levy, J. Lipid Res., 19, 667 (1978)

2) S. Eisenberg, R.I. Levy, Adv. Lipid Res., 13, 1-89 (1975)

3) J.D. Morrisett, R.L. Jackson, A.M. Gotto Jr., Ann.
Rev. Biochem., 44, 183 (1975)

4) J.D. Morrisett, R.L. Jackson, A.M., Gotto Jr., Biochim. Biophys. Acta, 472, 93 (1977)

5) A. Nicoll, N.E. Miller, B. Lewis, Adv, Lipid Res., 17, 53 (1980)

6) B.W. Shen, A.M. Scanu, F.J. Kézdy, Pro. Natl. Acad. Sci. USA, 74, 837 (1977)

7) D. Rudman, L.A. Garcia, L.L. Abell, S. Akgun, Biochemistry. 7, 3136 (1968)

8) L.C. Smith., H.J. Pownall., A.M. Gotto Jr., Ann. Rev. Biochem., 47, 751 (1978)

9) C. Edelstein, F.J. Kézdy, A.M. Scanu, B.W., Shen, J. Lipid. Res., 20, 143 (1979)

10) T. Gordon, W.P. Castelli, M.C. Hjortland, W.B. Kannel, T.R. Dawer, Am. J. Med., 62, 707 (1977)

11) S. Hulley, P. Ashman, L. Kuller, N. Lassen, R. Sherwin, Lipids, 14, 119 (1979)

12) A.R. Tall, D.M. Small, Adv. Lipid Res., 17, 1 (1979)

13) R.M. Krauss, F.T. Lindgren, J. Wingerd, D.D. Bradley, S. Ramcharan, Lipids, 14, 113 (1979)

14) J.J. Albers, G.R. Warnick, M.C. Chenng, Lipids, 13, 926 (1978) 